\title{
Correction to: Seismic control of buildings with active tuned mass damper through interval type-2 fuzzy logic controller including soil-structure interaction
}

\author{
Siamak Golnargesi ${ }^{1}$ (D) Hashem Shariatmadar ${ }^{2} \cdot$ Hessam Meshkat Razavi $^{3}$
}

Published online: 20 June 2018

(C) Springer International Publishing AG, part of Springer Nature 2018

\section{Correction to: Asian Journal of Civil Engineering (2018) 19:177-188 https://doi.org/10.1007/s42107-018- 0016-5}

The original version of this article unfortunately contained mistakes. The affiliation of Hessam Meshkat Razavi was incorrect. The corrected affiliation is given below.

${ }^{3}$ Islamic Azad University, Torbat-e-Heydarieh Branch, Torbat-e-Heydarieh, Iran

Siamak Golnargesi

Golnargesi.siamak@gmail.com

1 Faculty of Civil Engineering and Environment, Khavaran Institute of Higher Education, Fallahi Square, Mashhad, Iran

2 Department of Civil Engineering, Ferdowsi University of Mashhad, Azadi Square, Mashhad, Iran

3 Islamic Azad University, Torbat-e-Heydarieh Branch, Torbat-e-Heydarieh, Iran 